Scientific Journal of October 6 University

ISSN (Print): 2314-8640

ISSN (Electronic): 2356-8119

Published by October 6 University (C) All Rights Reserved

Available online at: http:// sjou.journals.ekb.eg
Citation: Helal et al., Antitumor and antioxidant activity of gold nanoparticles: In vitro and in vivo study Sci. J. of Oct. 6 Univ.3(2), 28-34. Copyright: (C) 2016 Helal et al. This is an open-access article distributed under the terms of the Creative Commons Attribution License, which permits unrestricted use, distribution, and reproduction in any medium, provided the original author and source are credited.

Original Article

\title{
Antitumor and Antioxidant Activity of Gold Nanoparticles: In vitro and In vivo Study
}

\author{
Helal $\mathrm{AI}^{1}$, El Baz $\mathrm{AF}^{1}$ and Rizk Nashwa $\mathrm{M}^{2}$ \\ ${ }^{1}$ Industrial Biotechnology Department, GEBRI Institute, Sadat City University, Egypt \\ ${ }^{2}$ Environmental Biotechnology Department, GEBRI Institute, Sadat City University, Egypt
}

Received: 23-03-2016 Revised: 5-04-2016 / Accepted: 22-5-2016

\begin{abstract}
Gold nanoparticles (AuNPs) have been tested in vivo and in vitro for its antioxidant and antitumor activity, cytotoxicity of AuNPs have been studied in vitro and found that a concentration of $7 \mathrm{mg} / \mathrm{ml} \mathrm{decrease}$ the EAC count by $41.8 \%$. There was a very high significant increase in catalase (CAT) activity by $90.6 \%$ and very high significant decrease in malonodialdehyde (MDA) level, alanine aminotransferase (ALT), aspartate aminotransferase (AST) and serum creatinine by $30.8 \%, 36.1 \%, 27 \%$ and $56.1 \%$ respectively.
\end{abstract}

Key Words: Gold nanoparticles, antioxidant, antitumor and cytotoxicity.

\section{Introduction}

Gold is a chemical element with symbol Au and molecular weight of 196.96. Gold is a noble metal and has nontoxic characteristics. It is stable to oxidation compared to other metals and is not easily affected by an acidic environment ( $\mathrm{Lu}$ et al., 2007).

Gold has been already reported as a health adjuvant. Its unique properties like inertness, nontoxic nature towards cell and biocompatibility of gold make it useful and attractive materials for the researchers for biological and biomedical applications as well as relevant in therapy and imaging (Faraji and Wipf, 2009; Ker et al., 2008) . Today gold, especially gold nanoparticles (AuNPs) has become an important biomedical tool for scientists in cancer research due to several advantages of AuNPs. Recently several researches demonstrated that AuNPs possess an enormous potential to improve the efficacy of cancer treatment (Esther et al., 2005).

AuNPs can be engineered in different ways to detect a stimulus, such as molecular binding events or ionic concentration changes, and respond immediately by releasing cargo into the cells or tissue, degrading or even carrying out the chemical modification of drugs in vitro and in vivo. In addition to the potential application of nano-based materials to combine multiple therapeutic functions into a single platform, these nanoparticles can also be targeted to specific tissues, thus, reaching sub- cellular compartments or malignant at different stages (Kumar, 2011).

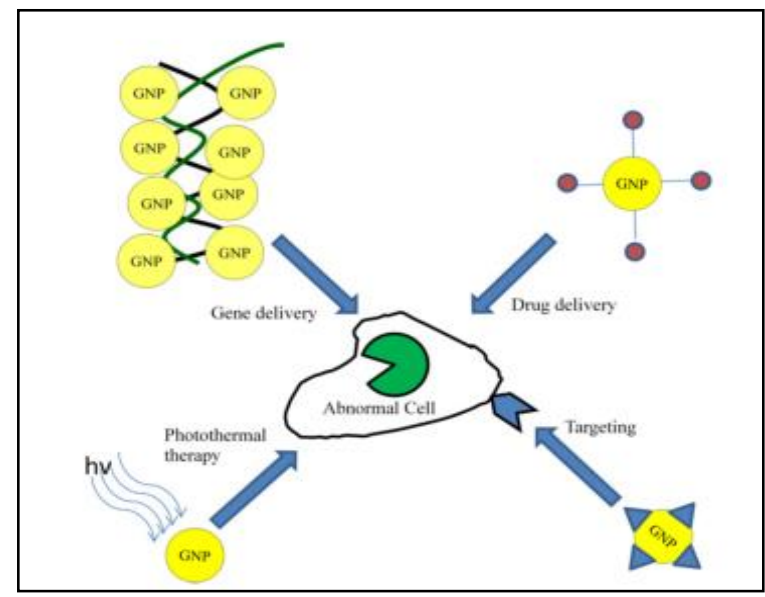

Fig(1). Various applications of AuNPs in therapy (Alanazi et al., 2010).

In this study we will examine the efficacy and safety of the AuNP in vivo and in vitro against Ehrlich Ascites Carcinoma Cells.

Ehrlich tumor or Ehrlich Ascites Carcinoma (EAC) is a transplantable neoplasia from a malign epithelium, which corresponds to mammary adenocarcinoma in female mice. When inoculated intra peritoneal it grows in an ascetic form, Ascites liquid is gray white, or sometimes has a light bloody viscose liquid. 
Ehrlich tumor is a rapidly growing carcinoma with very aggressive behavior (Gupta et al., 2004). It has been reported that Ehrlich ascites tumor cells lack H-2 histocompatibility antigens, which apparently is the reason for their rapid proliferation in almost any mouse host. Since the description of Ehrlich ascites, researchers exploit it for chemotherapeutic studies.

\section{Material and methods \\ 1 Materials}

RPMI1640 (Roswell Park Memorial Institute) medium with L-glutamine (Cambrex, Belgium), $\mathrm{HAuCl}_{4}$, Trypan Blue (Sigma, USA). Biochemical kits were purchased from local market, Ehrlich Ascites Carcinoma Cells (EAC) were purchased by the National Cancer Institute (NCI), Cairo University, Egypt, and was maintained by weekly intra-peritoneal transplantation of $2.5 \times 10^{6} / \mathrm{ml}$ cells in female Swiss albino mice.

\section{Experimental animals}

Forty five female Swiss albino mice, 12-14 weeks old age and weighing about 20-25 g (obtained from Laboratory Animals Research Center, Faculty of Veterinary Medicine, Zagazig University, Egypt) were used throughout this study. The animals were housed in steel mesh cages (10-15 mice per cage), in animal house, Faculty of science, Zagazig University, Egypt and allowed to become acclimatized to laboratory conditions for one week before the experiment.

\section{Gold Nano Particles (AuNP) preparation}

AuNP was prepared according to Rajesh et al., (2012). Briefly $200 \mathrm{ml}$ of $1 \mathrm{mM} \mathrm{HAuCl}_{4}$ was boiled and stirred under the reflux condition for 30 min. $20 \mathrm{ml}$ of $38.8 \mathrm{mM}$ aqueous tri-sodium citrate was added directly into the boiled solution. The color of the solution changed from pale yellow to deep red within 7-10 min after the addition. Further the reaction was continued for additional $\sim 20 \mathrm{~min}$ after which $20 \mathrm{mg}$ of polyvinyl pyrrolidone (PVP, M.W=40,000) in $30 \mathrm{ml}$ of water was added to the above solution and stirred for the next $45 \mathrm{~min}$. The solution was cooled at room temperature

\footnotetext{
4 Determination of AuNP size using Scanning Electron microscope (SEM)

Aliquots of GNPs were adsorbed on form of carbon-coated copper grids (400 mesh).The grid was placed in contact with a $10 \mathrm{~mL}$ droplet of the colloidal dispersion for a few minutes; excess solution was removed with a filter paper and later the sample was dried in air. Samples were imaged on a Philips CM120 electron microscope operating at $20 \mathrm{kV}$.The diameter distribution of GNPs was analyzed with Image software.
}

5 Cytotoxicity assay against Ehrlich Ascites Carcinoma (EAC) cells by trypan blue exclusion method:

This test was done according to Ribeiro et al., (2006) briefly Ascites fluid was withdrawn under aseptic conditions from the peritoneal cavity of tumor bearing mice by needle aspiration after 7 days of EAC cells inoculation. To adjust the number of EAC cells $/ \mathrm{ml}$, tumor cells obtained was diluted several times with normal saline. EAC viable cells were counted by trypan blue exclusion method where, $10 \mu \mathrm{l}$ trypan blue $(0.05 \%)$ was mixed with $10 \mu \mathrm{l}$ of the cell suspensions. Within 5 minutes, the mixture was spread onto haemocytometer, covered with a cover slip and then cells were examined under microscope. Dead cells are blue stained but viable cells are not.

\section{Determination of Serum Lipid Peroxide (Malodialdehyde)}

Malodialdehyde (MDA) was determined by using Biodiagnostic kit according to the method of Satoh (1978). Briefly $0.2 \mathrm{ml}$ of serum mixed well with $1.0 \mathrm{ml}$ chromogen and heated in a water bath for 30 minutes then get reading using UV-200-Rs spectrophotometer (Lw scientific, Umedic, Germany) at $534 \mathrm{~nm}$.

\section{Assessment of catalase enzyme activity (CAT)}

This test was done according to Aebi, (1984), briefly $0.05 \mathrm{ml}$ from serum sample mixed well with $0.05 \mathrm{ml}$ of phosphate buffer $100 \mathrm{mM} / 1,0.1 \mathrm{H}_{2} \mathrm{O}_{2}$ $500 \mathrm{mM} / 1$ then incubate tubes for exactly one minute at $25 \mathrm{C}$ then add $0.2 \mathrm{ml}$ chromogen inhibitor and $0.5 \mathrm{ml}$ 4-Aminoantipyrine preservative $2 \mathrm{mM} / 1$ and peroxidase > 2000/l. All tubes were incubated $10 \mathrm{~min}$ at $37^{\circ} \mathrm{C}$, read sample against sample blank and standard against standard blank at $510 \mathrm{~nm}$ using ECO 308 BIOCHEMISTRY ANALYSER. Color is stable for one hour.

\section{Determination of plasma alanine aminotransferase (ALT/ GPT)}

This test was done according to Schumann and Klauke, (2003) , briefly at $37{ }^{\circ} \mathrm{C}$ Pipette into cuvettes $100 \mu$ of sample to $1000 \mu$ of working solution which composed of TRIS buffer ( $\mathrm{pH} 7.5)$ $150 \mathrm{mmol} / \mathrm{l}$, L-alanine $750 \mathrm{mmol} / \mathrm{l}, \mathrm{LDH}>1.2$ KU/l ,2-oxoglutarate $90 \mathrm{mmol} / \mathrm{l}$ and NADH 0.9 $\mathrm{mmol} / \mathrm{l}$, Mix, read the absorbance after 1 minute and at the same time start the stop watch, read the absorbance again exactly after 1.2 and 3 minutes.

\section{Determination of plasma aspartate} Aminotransferase (AST/ GOT)

This test was done according to Karmen et al., (1955), briefly at $37^{\circ} \mathrm{C}$ Pipette into cuvettes $100 \mu$ of sample to $1000 \mu \mathrm{l}$ of working solution which composed of -TRIS buffer (PH 7.8) [100 mmol/l]; 
L-aspartate $\quad[300 \mathrm{mmol} / \mathrm{l}] ; \mathrm{LDH} \quad$ [> $0.9 \mathrm{KU} / \mathrm{l}]$; and MDA [>0.6 KU/l] Substrates: 2oxoglutarate $\quad[60 \mathrm{mmol} / \mathrm{l}]$; and NADH $[0.9$ $\mathrm{mmol} / \mathrm{l}]$ and, Mix, read the absorbance after 1 minute and at the same time start the stop watch, read the absorbance again exactly after 1.2 and 3 minutes.

\subsection{Determination of Serum Creatinine}

Add $0.5 \mathrm{ml}$ of Picric acid (17.5 mmol/L) in standard and test tubes. Add $0.5 \mathrm{ml}$ of sodium hydroxide $(0.29 \mathrm{~mol} / \mathrm{L})$ in standard and test tubes. Add $100 \mu \mathrm{l}$ of creatinine aqueous primary standard ( $2 \mathrm{mg} / \mathrm{dl})$ in standard tube. Add $100 \mu \mathrm{l}$ of sample (plasma) in test tube. Mix and start stopwatch. Read the absorbance (A1) after 30 seconds and after 120 seconds (A2) of the sample addition.

\subsection{Statistical Analysis}

All statistical analyses were done by social science package "SPSS" 14.0 for Microsoft Windows, SPSS Inc. (Levesque, 2007) and considered statistically significant at a two-sided $\mathrm{P}<0.05$. Numerical data were expressed as mean \pm SD. The levels of markers were analyzed by ANOVA. The correlations between serum biochemical data in different studied groups were evaluated by Person's correlation coefficient, to quantify the relationship between the studied parameters. $\mathrm{P}$ value $<0.01$ was considered significant.

\section{Results \\ 1 Determination of AuNP size using Scanning Electron microscope (SEM) \\ Fig. $1(a, b)$ presents a typical Scanning electron microscope (SEM) image of spherical AuNPs synthesized by the Gangwar method . The analysis of the size distribution results in an average diameter of $344 \mathrm{~nm}$.}

\section{Cytotoxicity assay against Ehrlich Ascites Carcinoma (EAC) cells by trypan blue exclusion method}

Fig (2) summarizes the data of Nano-Gold concentration cytotoxicity against EAC cells after I hour of incubation. The data were expressed as surviving percent compared with untreated control cells. Treatment of EAC cells with Nano-Gold concentration at increasing concentrations (1-7 $\mathrm{mg} / \mathrm{ml}$ ) for one hour showed increase in cytotoxicity of EAC cells with the increase in concentration. With high toxicity reached to 41.8 at concentration of $7 \mathrm{mg} / \mathrm{ml}$ Nano-Gold.

\section{Determination of Serum Lipid Peroxide (Malodialdehyde)}

Data obtained from Fig: (3) summarizes the effect of AuNP on the MDA level in mice studied group. The mean of MDA levels were a very highly significant increase $(\mathrm{p}<0.001)$ to $42.10 \pm 2.61$ $(\mathrm{nmol} / \mathrm{ml})$ in the positive control group compared to the negative control group $11.49 \pm 0.83$ (nmol/ml). Meanwhile, the mean MDA levels showed a very highly significant decrease to 29.12 $\pm 3.33(\mathrm{nmol} / \mathrm{ml})$ by $30.8 \%(\mathrm{p}<0.001)$ in nano-gold solution compared to the positive control group.

\section{Assessment of catalase enzyme activity.}

The effect of AuNP on the catalase activity in mice studied group is illustrated in Fig. (4). The mean of catalase activities were a very highly significant decrease $(\mathrm{p}<0.001)$ to $152.87 \pm 10.32(\mathrm{U} / \mathrm{L})$ in the positive control group as compared to the negative control group 237.69 \pm 15.22 (U/L). While, the mean catalase activities showed a very highly significant increase to $291.35 \pm 9.1$, (U/L) by 90.6 $\%,(\mathrm{p}<0.001)$ in nano-gold solution compared to the positive control group.

\section{Determination of plasma alanine amino transferase (ALT/ GPT)}

Data obtained from Fig. (5) summarizes the effect of AuNP on the plasma ALT activity (U/L) in mice studied groups. ALT activity revealed a very highly significant increase $(\mathrm{p}<0.001) 180.92 \pm 18.09$ (U/L) in positive control group as compared to negative control group $49.40 \pm 8.37$ (U/L). While, ALT activity (U/L) showed a very highly significant decrease to $115.60 \pm 5.25$ (U/L) by $36.1 \%$, $(\mathrm{p}<0.001)$ in nano-gold solution compared to the positive control group.

\subsection{Determination of plasma aspartate} aminotransferase (AST/ GOT)

Data obtained from Fig. (6) summarizes the effect of AuNP on the plasma AST activity (U/L) in mice studied groups. AST activity (U/L) revealed a very highly significant increase $(p<0.001)$ to 234.79 $\pm 15.44 .1(\mathrm{U} / \mathrm{L})$ in positive control group as compared to negative control group $82.60 \pm 3.09$ (U/L). But, AST activity (U/L) showed a very highly significant decrease to $171.47 \pm 9.53$, (U/L) by $27 \%,(p<0.001)$ in nano-gold solution compared to the positive control group.

\subsection{Determination of serum creatinine}

Fig. (7) summarize the effect of AuNP on the creatinine concentration in mice studied groups. The resulted data revealed a very highly significant increase in the creatinine concentration $(\mathrm{p}<0.001)$ to $2.21 \pm 0.49(\mathrm{mg} / \mathrm{dl})$ in positive control group compared to negative control group $0.45 \pm 0.13$ $(\mathrm{mg} / \mathrm{dl})$. Meanwhile, it revealed a very highly significant decrease to $0.97 \pm 0.06(\mathrm{mg} / \mathrm{dl})$ by $56.1 \%$, $(\mathrm{p}<0.001)$, in nano-gold solution compared to the positive control group.

\section{Discussion}

In vitro study of the AuNP toxicity was focused mainly on counting the cells remains alive after 
exposure of increasing dose concentration of AuNP and according to the data in Fig. 2 that reveals the highest cell toxicity percentage was $41.8 \%$ at concentration of $7 \mathrm{mg} / \mathrm{ml}$.

EAC cells is originated from breast cancer which was modified to be grown in female Swiss albino mice and maintained by intraperitoneal inoculation of carcinoma cells in the mice.

In the present study, application of nano-gold solution on EAC cells showed increase in cytotoxicity of EAC cells with increase in concentration.

It was found that AuNP induced cell apoptosis in the EAC and DNA fragmentation in the cells and this is matching the results of Kondath et al., (2014) as he tested the effect of AuNP on MCF-7 cells.

In vivo nanoparticles toxicity and safety studies are focused mainly on examining changes in blood serum chemistry; These in vivo studies not only provide the toxicity information unavailable through in vitro studies but also inform the choice of relevant model system for carrying out further in vitro studies. Oxidative stress is a normal cellular process involved in numerous aspects of cellular signaling. Oxidative stress results as a consequence of an imbalance between the production and manifestation of reactive oxygen species (ROS), and the ability of biological systems to readily detoxify the reactive intermediates or to repair the resulting damage. Peroxidation of lipids is known to be a free radical-mediated chain reaction leading to the damage of the cell membrane (Koiram et al., 2007). In the present study, implantation of Ehrlich carcinoma tumor into female Swiss albino mice has been proved to induce significant deleterious changes in antioxidant status. The results revealed a very highly significant increase in lipid peroxidation level and a very highly significant decrease in CAT activity in the blood of Ehrlich carcinoma bearing mice.

Special attention has been devoted to study the systemic effects of the tumor on the host. It had been postulated that the existence of tumor leads to two main interconnected forms of the systemic effect: (a) competition of the tumor with the host tissues for nutrients and vital factors and (b) alteration of biological characteristics of distant organs. In this respect it has been reported that, the presence of tumor in human body or in experimental animals is known to affect many functions of the vital organs in the body (including liver and kidney) even when the site of the tumor doesn't interfere directly with the functions of these organs (DeWys, 1982).

In the present study, it was found that presence of Ehrlich carcinoma led to some liver and kidney dysfunctions. The biochemical analysis showed elevation in AST, ALT, urea and creatinine in plasma of tumor bearing mice. The most sensitive markers employed in the diagnosis of hepatic dysfunction are serum AST and ALT because they are located in the cytoplasm of hepatocytes and are released into the circulation after cellular damage. In our results, treatment with AuNP showed a very highly significant increase in catalase activity and a very highly significant decrease in MDA levels compared to the positive control group.

It was reported that the antioxidant activity of the AuNPs with respect to hydroxyl radicals considerably depends on the specific surface area of the nanoparticles. AuNPs can be a promising candidate for antioxidant action, as they inhibit the formation of ROS, scavenging free radicals, thus increasing the anti-oxidant defense enzymes of the body and creating a sustained control over hyperglycemic conditions that will prove to be very beneficial in diabetic treatment (Khan et al., 2013)

\section{Conclusion}

As demonstrated from the above results AuNP is a promising therapeutic agent against tumors as its nontoxic and has a relatively high antioxidant activity which can accommodate for AuNP to be adjuvant therapy in case of tumors. Gold is nonreactive metal or noble metal as described in chemistry and this criteria is very important in decreasing the side effect of the therapeutic dose of gold. Converting gold to gold nano particles was very important to decrease the concentration of the dose which will has a therapeutic effect.

Conflict of Interest Statement: The author declares no conflicts of interest. 


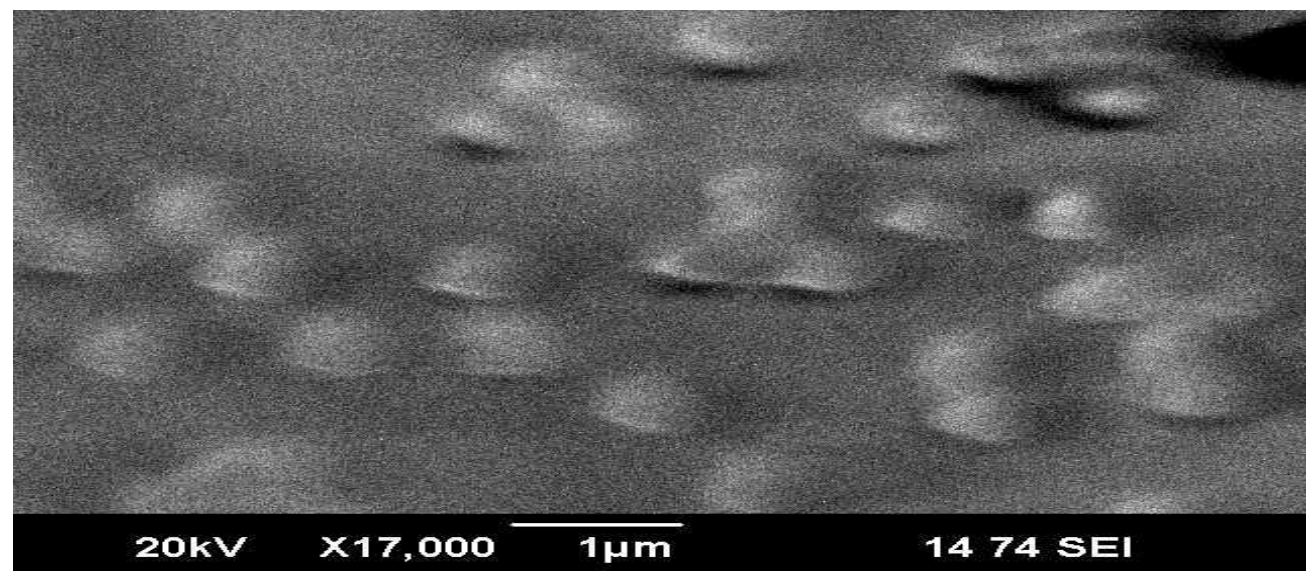

(a)

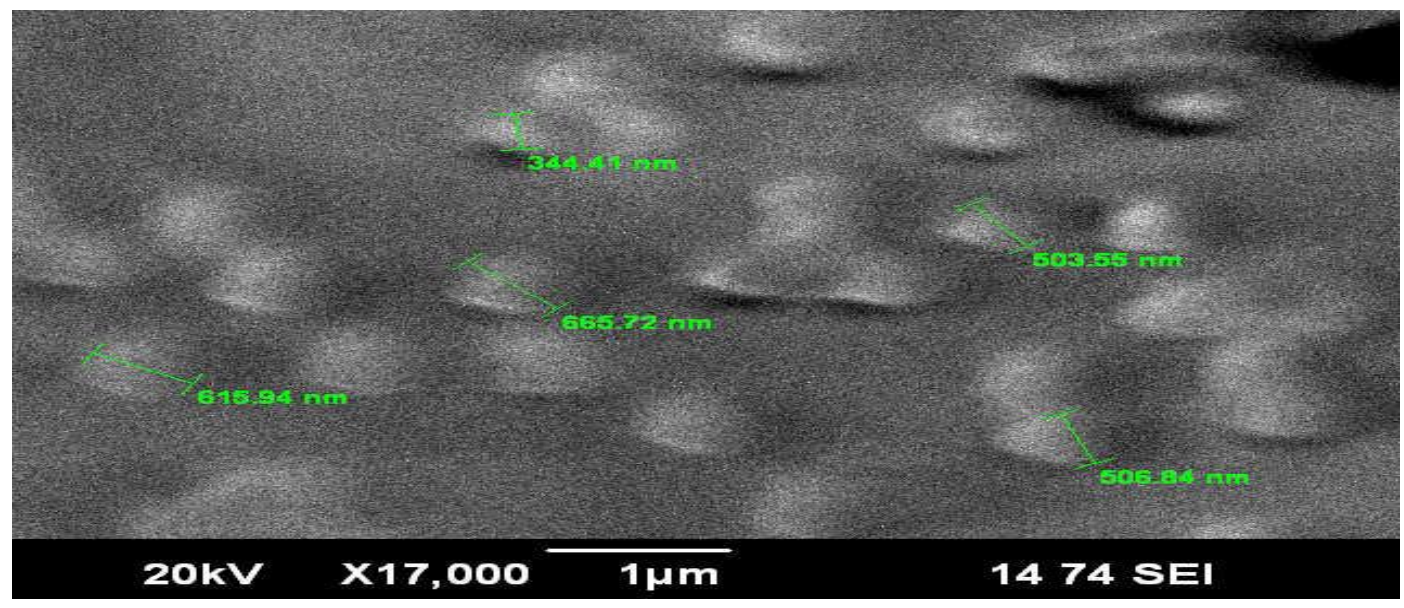

(b)

Fig. (1a\&b): Determination of AuNp size using Scanning Electron Microscope (SEM).

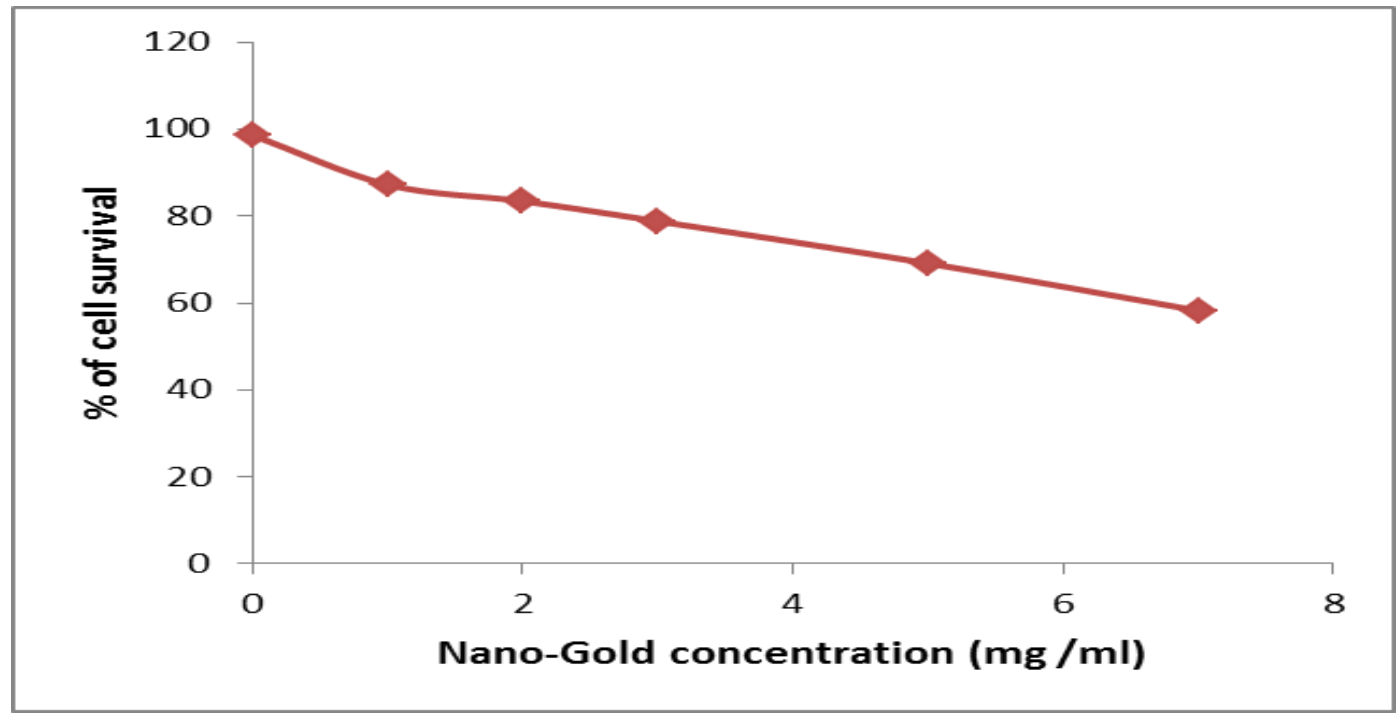

Fig. (2). Cytotoxicity of Nano-Gold against Ehrlich Ascites Carcinoma (EAC) cells. 


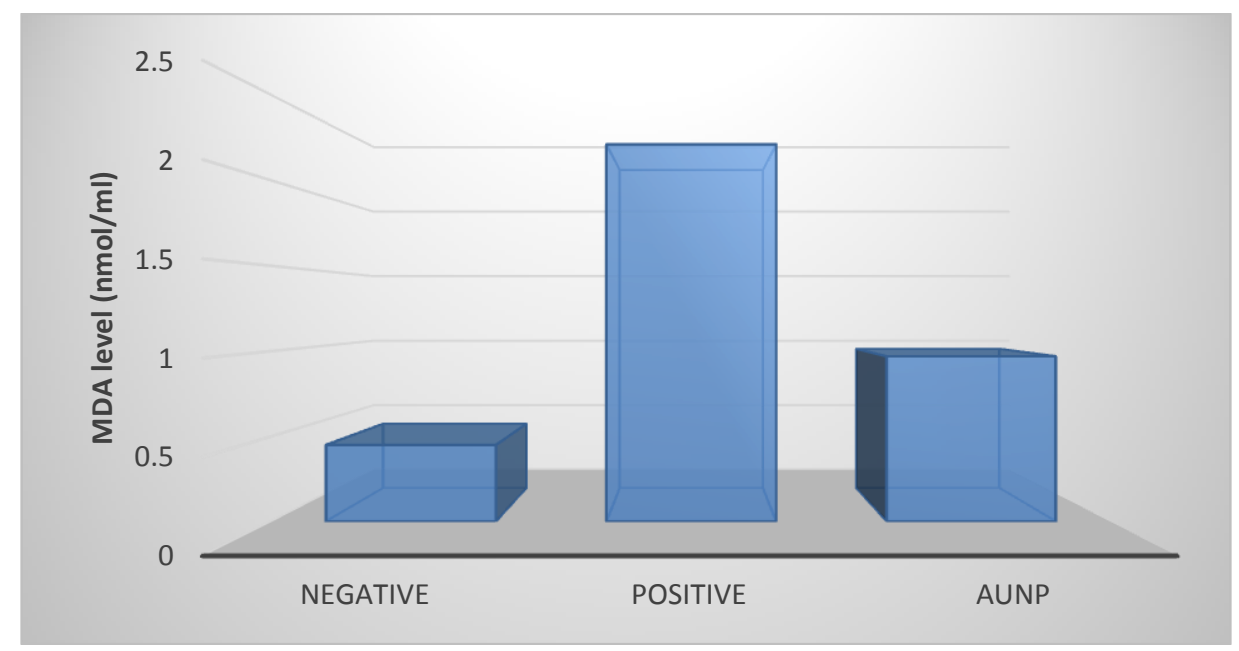

Fig. ( 3) : Effect of AuNP on the MDA level (nmol/ml) in mice studied groups.

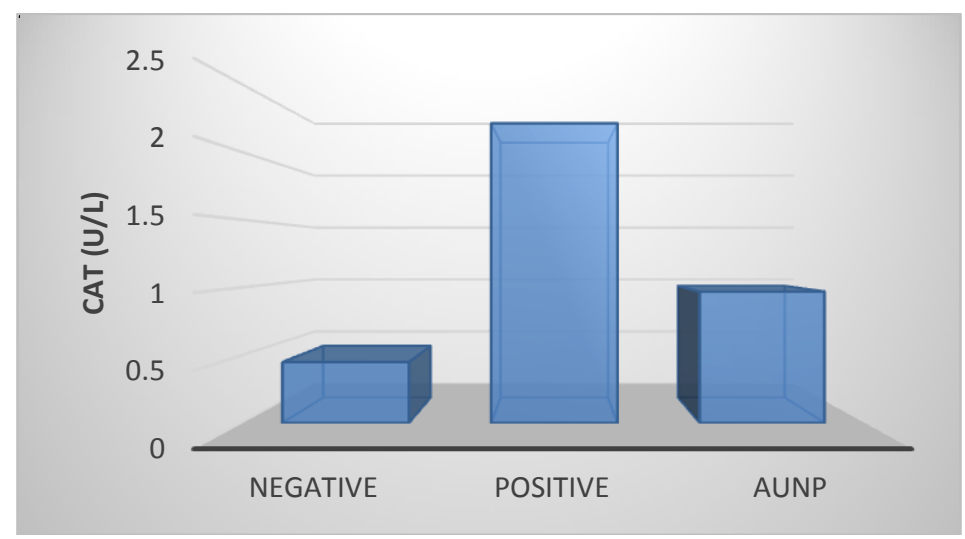

Fig. (4): Effect of AuNP on the catalase activity (U/L) in mice studied groups.

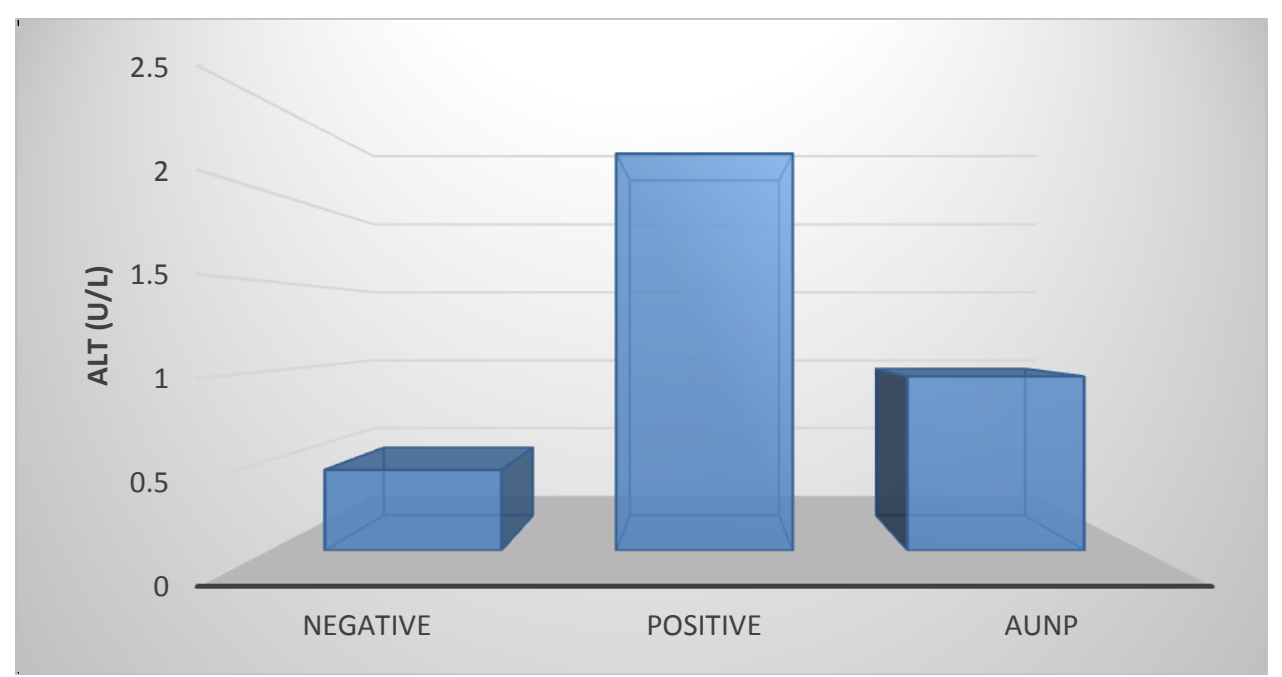

Fig. (5): Effect of AuNP on the plasma ALT activity (U/L) in mice studied groups. 


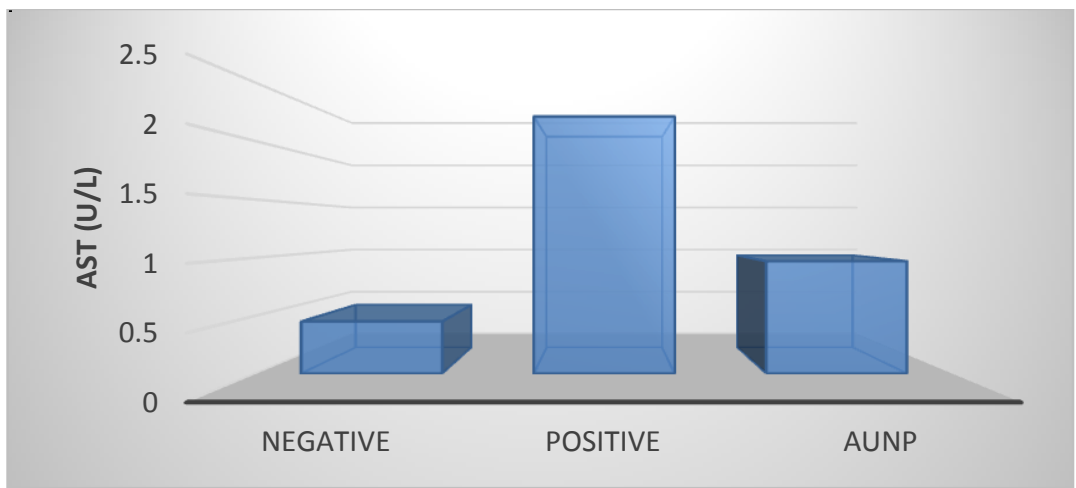

Fig. (6): Effect of AuNP on the plasma AST activity (U/L) in mice studied groups.

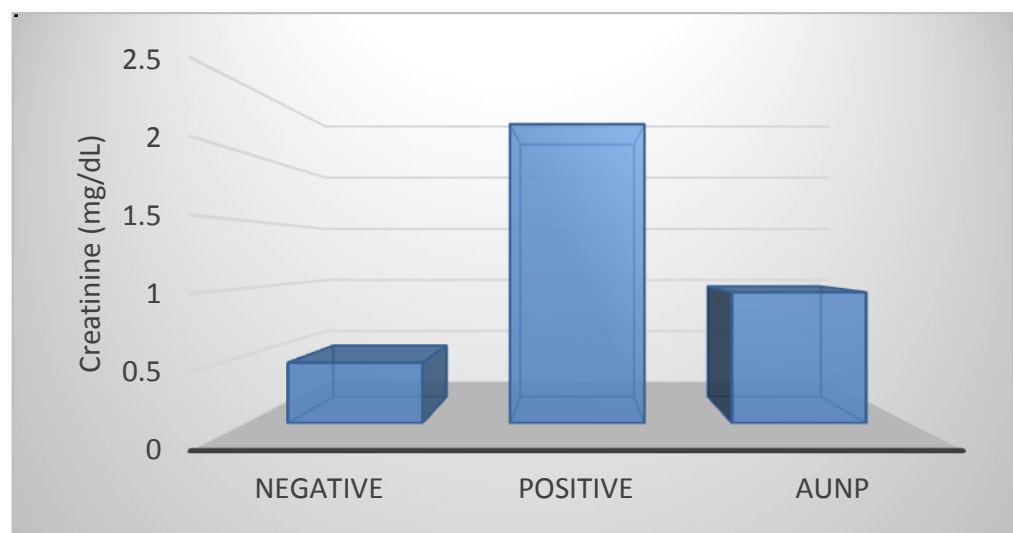

Fig. (7): Effect of AuNP on the blood creatinine concentration (mg/dl) in mice studied groups.

\section{References}

Aebi H (1984). Catalase in vitro, Methods Enzymol 6:105:121. Alanazi FK, Radwan AA, Alsarra IA (2010). Biopharmaceutical application of nanogold, Saudi Pharmac. J. 18(4) 179- 193

DeWys WD (1982). Pathophysiology of cancer cachexia: current understanding and areas for future research. Cancer Res. 42(2 Suppl):721s-726s.

Esther RJ, Bhattacharya R, Ruan M, Bolander ME, Mukhopadhyay D, Sarkar G, Mukherjee P. (2005). Gold nanoparticles do not affect the global transcriptional program of human umbilical vein endothelial cells: a DNA-microarray analysis, J. Biomed. Nanotech. 1; 328-335.

Faraji AH, Wipf P. (2009). Nanoparticles in cellular drug delivery.Bioorg Med Chem. 17:2950-62.

Gupta A, Mazumder UK, Kumar RS, Kumar TS (2004). Anti-tumor activity and anti-oxident role of Bauhinia racemosa against Ehrlich ascites carcinoma in Swiss albino mice. Act. Pharm. Sin. 25(8): 1070-1076.

Karmen A, Wroblewski F, LaDue JS(1955). Transaminase activity in human blood. J. Clin. Invest 34:126-31.

Ker N, Hall WP, Lyandres O, Shah N, Zhao J, Van Duyne RP.(2008). Biosensing with plasmonic nanosensors. Nat Mater. 7:442-53.

Khan MS, Vishakante GD, Siddaramaiah H(2013). Gold nanoparticles: A paradigm shift in biomedical applications. Adv Colloid Interface Sci. 199-200:44-58

Koiram PR, Veerapur VP, Kunwar A, Mishra B, Barik A, Priyadarsini IK, Mazhuvancherry UK(2007). Effect of Curcumin and Curcumin Copper Complex (1:1) on Radiationinduced Changes of Anti-oxidant Enzymes Levels in the Livers of Swiss Albino Mice. J. Radiat. Res., 48(3) 241-245.

Kondath S, Raghavan BS, Anantanarayanan R, Rajaram R

(2014). Synthesis and characterisation of morin reduced gold nanoparticles and its cytotoxicity in MCF-7 cells. ChemicoBiological Interactions. 224: 78-88
Kumar S. (2011). Free radicals and antioxidants: Human and food system. J. Advances in Applied Science Res., 2(1):129-135. Levesque R. SPSS., (2007): Programming and Data Management: A Guide for SPSS and SAS Users, Fourth Edition, SPSS Inc., Chicago Ill.

Lu AH, Salabas EL, Schüth F. (2007). Magnetic nanoparticles: synthesis, protection, functionalization, and application. Angew Chem Int Ed 46: 1222-44.

Rajesh KG, Vinayak A, Dimple K, Umesh TN, Gosavi SW, Rishi BS, Kale SN, Suwarna D. (2012). Conjugation of curcumin with PVP capped gold nanoparticles for improving bioavailability, Mat.. Sci. and Eng. C 32 2659-2663

Ribeiro DA, Marques ME, Salvadori DM. (2006). In vitro cytotoxic and non-genotoxic effects of Gutta- Percha solvents on mouse lymphoma cells by single cell gel (comet) assay. Braz Dent J., 17(3):228-232.

Satoh K (1978). Serum Lipid Peroxide in cerebrovascular disorders determined by a new colorimetric method. Clinica Chimica Acta 90:37-43.

Schumann G, Klauke R (2003). New IFCC reference procedures for the determination of catalytic activity concentrations of five enzymes in serum: preliminary upper reference limits obtained in hospitalized subjects. Clin. Chim. Acta., 327 (1-2): 69-79. 